\title{
Sprawozdanie z Interdyscyplinarnego Sympozjum „Nowoczesne terapie w dermatologii, gastroenterologii, reumatologii u dorosłych i dzieci”
}

\author{
Poznań, 8-9 września 2017 r.
}

Dermatol Rev/Przegl Dermatol 2017, 104, 575-577

W pierwszym powakacyjnym tygodniu września (8-9.09.2017) w Poznaniu spotkali się dermatolodzy z lekarzami innych specjalności. Tematem przewodnim kolejnego Interdyscyplinarnego Sympozjum z cyklu „Pod Poznańskimi Koziołkami” były nowoczesne terapie w dermatologii, gastroenterologii i reumatologii u dorosłych i dzieci. Już po raz trzeci do stolicy Wielkopolski zaproszono znanych naukowców, którzy zaprezentowali aktualne dane na temat leczenia i diagnostyki chorób o wielospecjalistycznym obrazie klinicznym.

Sympozjum odbyło się w Centrum Kongresowo-Dydaktycznym Uniwersytetu Medycznego w Poznaniu i uświetniło obchody 25-lecia Wydziału Lekarskiego II Uniwersytetu Medycznego w Poznaniu. Uczestników Sympozjum powitali przewodniczący i organizatorzy spotkania, a także pracownicy Uniwersytetu Medycznego im. Karola Marcinkowskiego w Poznaniu. Przewodniczącymi Komitetu Naukowego byli: prof. dr hab. Zygmunt Adamski, kierownik Katedry i Kliniki Dermatologii, prof. dr hab. Agnieszka Dobrowolska i prof. dr hab. Marian Grzymisławski z Katedry i Kliniki Gastroenterologii, Dietetyki i Chorób Wewnętrznych oraz prof. dr hab. Włodzimierz Samborski, kierownik Katedry Reumatologii i Rehabilitacji. Partnerstwo merytoryczne i nadzór naukowy, poza wspomnianymi powyżej ośrodkami, sprawował prof. dr hab. Ryszard Żaba, kierownik Zakładu Dermatologii i Wenerologii. W trakcie ceremonii otwarcia Sympozjum głos zabrała również prof. dr hab. Lidia Rudnicka, prezes Polskiego Towarzystwa Dermatologicznego, która wyraziła aprobatę dla interdyscyplinarnego charakteru konferencji. Wykład inauguracyjny przedstawił prof. dr hab. Jacek Wysocki, który omówił problematykę związaną ze współczesną wakcynologią, a zwłaszcza korzyści populacyjne wynikające ze szczepienia przeciwko meningokokom. W sesji inauguracyjnej odbył się wykład tandemowy z udziałem chirurga i gastroenterologa na temat leczenia nieswoistych zapaleń jelit (prof. dr hab. Grażyna Rydzewska oraz prof. dr hab.
Tomasz Banasiewicz). Najważniejszym punktem drugiej części sesji była debata ekspertów poświęcona leczeniu łuszczycy i łuszczycowego zapalenia stawów. Dyskusję otworzył prof. dr hab. Zygmunt Adamski, zadając pytania: Quo vadis leczenie biologiczne łuszczycy i łuszczycowego zapalenia stawów? Rewolucyjne podejście terapeutyczne - czy rzeczywiście, czy potrzebne są konsensusy? W wymianie opinii eksperckich wzięli udział prof. dr hab. Lidia Rudnicka, prof. dr hab. Andrzej Kaszuba, prof. dr hab. Witold Owczarek, dr hab. Agnieszka Osmola-Mańkowska, dr hab. Aneta Szczerkowska-Dobosz, natomiast reumatologów reprezentował prof. dr hab. Włodzimierz Samborski. Omówiono współczesne poglądy i stanowiska różnych środowisk na temat nowoczesnego leczenia łuszczycy.

W pierwszym dniu Sympozjum, w godzinach przedpołudniowych odbył się po raz pierwszy organizowany przez dermatologów kurs kapilaroskopii pod patronatem Polskiego Towarzystwa Dermatologicznego. Organizatorem kursu był Uniwersytet Medyczny w Poznaniu oraz firma Proyou. W czasie kursu dr hab. Aleksandra Dańczak-Pazdrowska przedstawiła wskazania do wykonania i zasady interpretacji obrazu kapilaroskopowego, podkreślając znaczenie tego badania w kryteriach kwalifikacyjnych twardziny układowej. Szkolenie na wideokapilaroskopie i kapilaroskopie cyfrowym z udziałem pacjentów przeprowadziły dr hab. Aleksandra Dańczak-Pazdrowska i dr med. Adriana Polańska z Poznania. Uczestnicy szkolenia otrzymali stosowne ceryfikaty.

Ważnym wydarzeniem podczas Sympozjum była sesja poświęcona grupom wsparcia dla chorych na łuszczycę, w której brali udział prof. dr hab. Lidia Rudnicka, prof. dr hab. Witold Owczarek, prof. dr hab. Andrzej Kaszuba, prof. dr hab. Ryszard Żaba oraz pracownicy Pracowni Łuszczycowej Katedry i Kliniki Dermatologii w Poznaniu. Wielkopolskie Stowarzyszenie Chorych na Łuszczycę „Wyjdź z Cienia" reprezentowała mgr Katarzyna Gerke, która na 


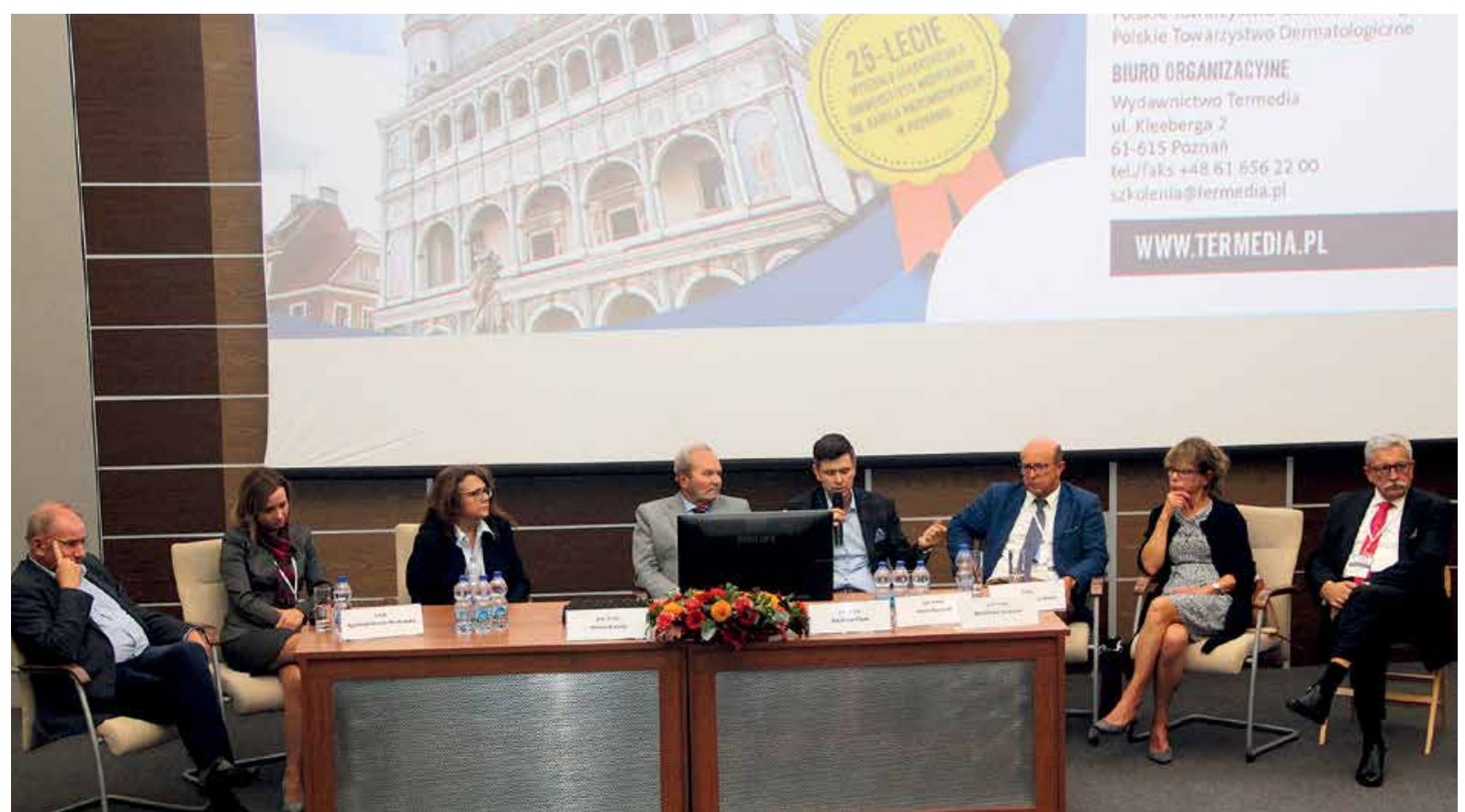

Rycina I. Panel dyskusyjny dermatologów i reumatologów dotyczący perspektyw nowoczesnej terapii łuszczycy

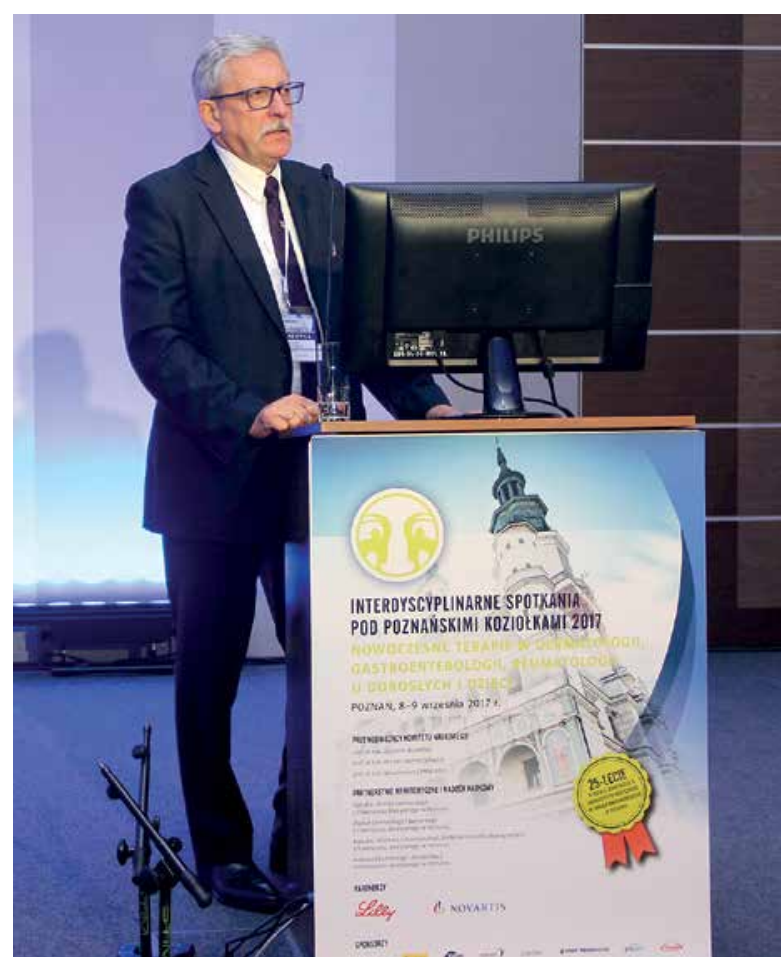

Rycina 2. Profesor Zygmunt Adamski, przewodniczący Komitetu Naukowego Sympozjum

podstawie badań własnych przedstawiła istotne zagadnienia dotyczące uświadamiania społeczeństwa na temat łuszczycy.

W drugim dniu obrad odbyło się spotkanie chorych na łuszczycę i ich przedstawicieli z prof. dr hab. Lidią Rudnicką. W spotkaniu brali udział

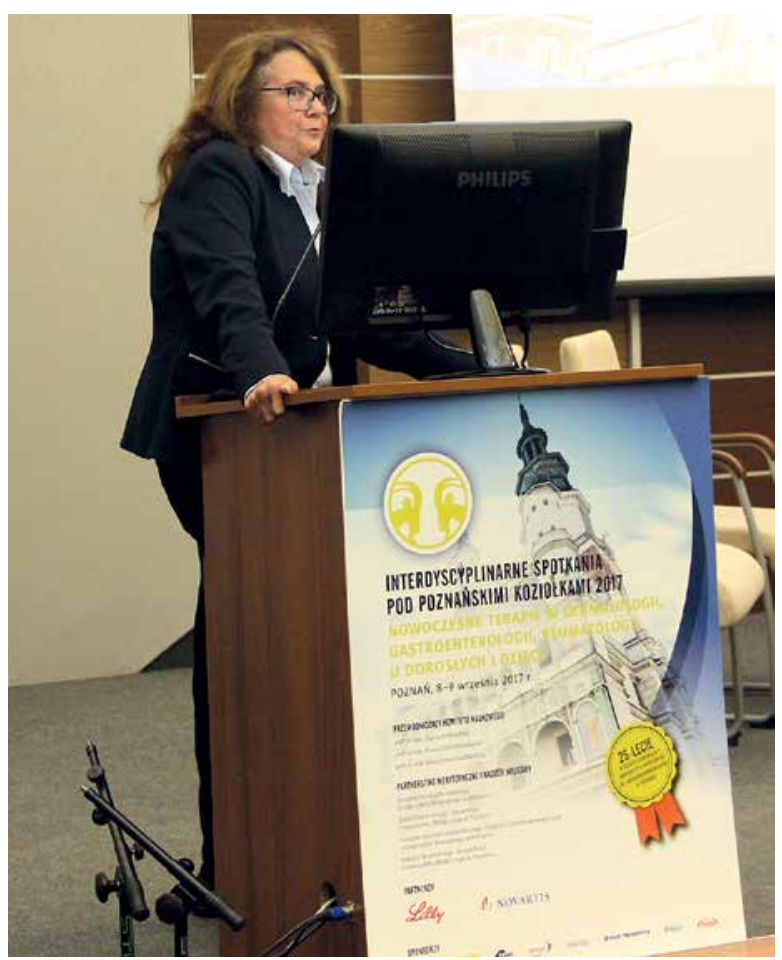

Rycina 3. Profesor Lidia Rudnicka, prezes Polskiego Towarzystwa Dermatologicznego

także prof. dr hab. Zygmunt Adamski, prof. dr hab. Witold Owczarek, prof. dr hab. Romuald Maleszka, prof. dr hab. Ryszard Żaba, dr hab. Agnieszka Osmola-Mańkowska i dr hab. Aleksandra Dańczak-Pazdrowska, konsultant w dziedzinie dermatologii i wenerologii dla województwa wielkopolskiego. 
Omówiono m.in. problematykę związaną z dostępnością terapii biologicznych w Polsce i rozszerzeniem kryteriów kwalifikujących do programów lekowych.

W sesji „Różne choroby, wspólne problemy” przedstawiono interdyscyplinarne zagadnienia z zakresu immunologii i genetyki chorób układu pokarmowego, skóry i stawów (dr hab. Jacek Karczewski, prof. dr hab. Ryszard Słomski), a także omówiono problemy ekonomiczne związane z nowoczesnymi terapiami (dr n. med. Rafał Staszewski). Profesor dr hab. Zygmunt Adamski w wykładzie "Nowoczesne podejście do leczenia łuszczycowego zapalenia stawów" podkreślił znaczenie terapii spersonalizowanej w łuszczycy, natomiast dr hab. Agnieszka Osmola-Mańkowska zwróciła uwage na problem immunogenności w terapiach biologicznych. Interdyscyplinarne spojrzenie na proces zapalny zaprezentowała dr med. Agnieszka Owczarczyk-Saczonek, natomiast zalety i wady metotreksatu omówiła dr hab. Aleksandra Dańczak-Pazdrowska.

W kolejnej sesji, zatytułowanej „Nowości terapeutyczne $\mathrm{w}$ dermatologii, gastroenterologii i reumatologii", przedstawiono nowoczesne leczenie wirusowych zapaleń wątroby (dr hab. Joanna Raszeja-Wyszomirska) oraz reumatoidalnego zapalenia stawów (prof. dr hab. Eugeniusz J. Kucharz, prezes Polskiego Towarzystwa Reumatologicznego). Znaczenie interleukiny $17 \mathrm{w}$ dermatologii $\mathrm{w}$ zakresie aktualnych możliwości terapeutycznych zaprezentował prof. dr hab. Zygmunt Adamski, natomiast dr hab. Dorota Jenerowicz omówiła nowoczesne zalecenia pielęgnacyjne i lecznicze w atopowym zapaleniu skóry.

Ostatnia sesja poświęcona była roli lekarza praktyka w nowoczesnym leczeniu chorób skóry, przewodu pokarmowego i stawów. Aspekty praktyczne terapii zaburzeń czynnościowych przewodu pokarmowego zaprezentowała dr hab. Agata Mulak, natomiast symptomatologię i terapię wybranych chorób reumatycznych podsumował prof. dr hab. Marek Brzosko, konsultant krajowy w dziedzinie reumatologii. Interdyscyplinarne spojrzenie na świąd w chorobach wewnętrznych przedstawił prof. dr hab. Jacek Szepietowski, który omówił m.in. leczenie świądu cholestatycznego i mocznicowego. Zastosowanie metotreksatu $\mathrm{w}$ terapii wybranych autoimmunizacyjnych chorób tkanki łącznej omówiła dr hab. Aleksandra Dańczak-Pazdrowska, podkreślając skuteczność tego leku w przewlekłym skórnym toczniu rumieniowatym, a także w morphea. Aktualną klasyfikację demodekozy, a także możliwości jej leczenia, w tym z wykorzystaniem stosowanego miejscowo olejku $\mathrm{z}$ drzewa herbacianego w nowej formule opracowanej w Poznaniu, zaprezentowała dr hab. Dorota Jenerowicz. Profesor dr hab. Marian Dmochowski omówił nowoczesne metody diagnostyczne i terapeutyczne w zespołach skórno-jelitowych.
Poznańskie Sympozjum było też miejscem prezentacji ciekawych, interdyscyplinarnych przypadków klinicznych przez dermatologów, gastroenterologów, a także reumatologów.

III Interdyscyplinarne Spotkanie pod Poznańskimi Koziołkami spełniło swoje cele - stworzyło możliwość wymiany poglądów i doświadczeń przez przedstawicieli różnych specjalności. Jesteśmy przekonani, że tego typu spotkania są przydatne w rutynowej praktyce lekarskiej. Mamy nadzieję, że nasze wielospecjalistyczne Sympozjum na trwałe wpisze się w kalendarz ważnych wydarzeń dermatologicznych, a jego kolejne edycje będą się cieszyć Państwa zainteresowaniem.

dr med. Adriana Polańska prof. dr hab. Zygmunt Adamski 